\title{
IMPROVING LITERACY SKILLS THROUGH THE LEARNING MODEL CHILD FIND IT IN CLASS IV SDN CIBEBER 1 CIMAHI
}

\author{
${ }^{1}$ Ruli Setiyadi and ${ }^{2}$ Naila Kurnia Restu \\ IKIP SILIWANGI \\ ${ }^{1}$ setiyadiruli@ikipsiliwangi.ac.id \\ ²nailakurnia97@gmail.com
}

\begin{abstract}
The research titled improving literacy skills through the learning model child find it in class iv sdn cibeber 1 cimahi based on the reduction of children ability in literacy skill in class IV. The method used in this research is Mix Method method (mixed qualitative and quantitative method) by comparing the learning outcomes of children before and after treatment. This research was conducted at SDN Cibeber 1 in South Cimahi District, Cimahi City. The results of this study is the increased ability to speak children as much as $70 \%$ after being given treatment find it. This shows that finding it can help improve children's literacy skills.
\end{abstract}

Keywords: Literacy, Learning Model Find It

\section{INTRODUCTION}

According to the National Institute for Literacy (2000), literacy is an individual's ability to read, write, speak, count and solve problems at the level of expertise required in work, family, and society. The development of Science and Technology (IPTEK) in Indonesia has many positive impacts in this country. However, beyond that there are negative impacts that affect the literacy ability of children especially among students. This is evidenced by the results of the study of 2012 UNESCO states that the interest of reading the Indonesian community is only $0.001 \%$. This means only 1 out of 1000 people who have interest in reading.

Students at SDN Cibeber 1 are not a few who are inhibited in the literacy ability to read, write and speak. This is caused by two factors, namely the environmental factors of the family and the school environment. In the family environment, students prefer watching television and playing gadgets - compared to reading books and writing. In addition to children's lack of interest in literacy, this can lead to a character indifferent to the surrounding social environment and dare not speak in public. While the causal factors in the school environment, namely in the process of learning a teacher's literacy using only monotonous teaching methods. For example students are given only a book of reading then students read it and summarize it together.

According to UNESCO (2012), people's understanding of the meaning of literacy is strongly influenced by academic research, institutions, national context, cultural values, as well as experience. Therefore, in this study the authors raised the understanding of elementary school students about literacy through their own experience. Because students 
will be easier in absorbing learning if they experience it directly. Then the author overcome by using various methods and effective learning model in improving students' literacy skills, especially in the school environment. One such effective learning model is Find It.

The benefit of this research is to know the factors that can inhibit the development of literacy capability in SDN Cibeber 1. Then get experience directly in overcoming the children who have less interest in literacy by using find it learning model. So that the interest and ability of class IV students can grow and develop well in SDN Cibeber 1.

Kern (2000) explains that:

Literacy is the use of social, historical, and cultural practices in creating and interpreting meaning through text. Literacy requires at least an unspoken sensitivity about the relationships between textual conventions and the context of their use and ideally the ability to reflect critically on those relationships. Being sensitive to purpose, the literacy is dynamic - not static - and may vary between and within the community and discourse / discourse culture. Literacy requires a range of cognitive abilities, written and spoken language knowledge, knowledge of genres, and cultural knowledge.

Based on the above explanation, it can be concluded that literacy is an activity that creates meaning through text and requires the ability of written and spoken language. Therefore, this study refers to social situational practices and implements meaning through text.

The learning model find it is the development of quantum learning method. "Quantum learning is a trick, a guide, a strategy and an entire learning process that can sharpen understanding and memory, and make learning as a fun enjoyable process" (Bobbi DePorter \& Mike Hernacki, 2011: 16).

The learning model finds it an effective and efficient way of developing literacy skills in reading, writing, and speaking of students in the school environment. It is undeniable that elementary students like a pleasant learning environment, because if it makes students happy then the material will be well received by students. With this learning model, students can learn to seek information through people around school, dictionary, book, or other media.

\section{METHODS}

The method used in this research is Mix Methode (Qualitative and Quantitative Mix Method). In the qualitative method it aims to explain in a descriptive and detailed description of the novel structure as well as the moral values contained therein. The research undertaken is done as objectively as possible towards the things that become the center of attention and support the research. Symptoms, events, events occurring at the time of the study will be described as-is. This is in line with the ideas of Sudjana and Ibrahim (2001, p. 64), which 
explains that descriptive methods are the methods used to describe a phenomenon, event, event occurring during the study.

In the use of the one-shot quantitative method case, Arikunto (2011, p. 257) suggests that:

experimental research is a study intended to determine whether there is a result of something done on the subject studied. Experimental research is known for two types: pure experiment (True experiment) and impure experiment (Quasi experiment). Improper experimental models or designs include: One-shot case model, one group pretest, post-test, prosstes - only group design.

The experimental method referred to in this study belongs to quasi experiments (experimental impurities) or in other words the experimental method is called One-group Experiments with the form of one-shot case study, where research conducted through an approach that uses data collection at a time then analyzed qualitatively.

\section{RESULTS AND DISCUSSION}

In accordance with the problems disclosed in the introduction, the action is carried out by applying the find it model to increase the literacy of fourth grade students SDN Cibeber 1 year lesson 2017/2018 with the number of subjects as many as 34 students.

In the early stages (before being treated), observation and recording of students 'ability in literacy and knowledge competence of the students' knowledge were used to know the initial state of the students. Based on these findings, there are problems regarding students' literacy skills and the vocabulary knowledge of students who are still relatively low. Details of the data can be explained in Table 1 .

Table 1. Table of Reflection Results in the early stages for literacy skills and Competence Mastery of Vocabulary Knowledge of Grade IV of SDN Cibeber 1

\begin{tabular}{|c|c|c|}
\hline Category & Results & Information \\
\hline $\begin{array}{l}\text { Literacy skills } \\
\text { a. Write } \\
\text { b. Read } \\
\text { c. Asking } \\
\text { d. Answer } \\
\text { e. Bring ideas } \\
\text { a. f. Solve the problem }\end{array}$ & $\begin{array}{l}\text { The average percentage } \\
\text { of students' literacy } \\
\text { ability is about } 68.75 \%\end{array}$ & $\begin{array}{l}\text { In general, the literacy } \\
\text { ability of fourth grade } \\
\text { students of SDN Cibeber } \\
1 \text { belong to category C }\end{array}$ \\
\hline
\end{tabular}




\begin{tabular}{|c|c|c|}
\hline $\begin{array}{l}\text { Mastery of vocabulary } \\
\text { knowledge } \\
\text { a. Average percentage } \\
\text { b. Percentage of classical } \\
\text { mastery }\end{array}$ & $\begin{array}{l}65,48 \% \\
40,76 \%\end{array}$ & $\begin{array}{l}\text { In general, the mastery of } \\
\text { students' vocabulary } \\
\text { knowledge is still } \\
\text { classified into category C } \\
\text { with classical } \\
\text { completeness belonging } \\
\text { to category C }\end{array}$ \\
\hline
\end{tabular}

The average percentage of literacy ability before the research was $68.75 \%$ with category $\mathrm{C}$. While the average value of knowledge knowledge of vocabulary before the research is $65.48 \%$ which is in category $\mathrm{C}$ with the percentage of classical completeness $40,76 \%$ with category $C$ that is 14 students completed and 20 students unfinished.

Based on the data acquisition of the research results at that stage, the completeness indicator has not been reached, so this research needs a special way by doing some improvement to get more maximal result and the completeness indicator is achieved. Specific way to be implemented in this research is by applying learning model find it. This stage is held for 35 minutes, consisting of 20 minutes for the learning process, and 15 minutes to discuss the work of each group. At this stage aims to improve the learning process. Stages performed on this particular way are as follows.

1. Students are divided randomly by teachers, one group consists of 4-5 people.

2. Students walk around the school to find a rolled-up piece of paper with a ribbon prepared by the teacher.

3. After students find it, students read an information on the paper. The information provided is the latest information that is being discussed by the public.

4. Once read, students are instructed to put an underscore on every word they do not understand.

5. Students read the next instruction, that is, one group is looking for the meaning of the words in KBBI and some are instructed to ask the people who are in the school environment in the same time, which is 20 minutes.

6. After the specified time runs out, students are directed to enter the class again and sit according to the group.

7. Each group makes the word "agree" and "disagree, because ..." in a single sheet of paper (back and forth),

8. Each group presented their work in front of the class, and the other students responded by presenting the paper "agree" and "disagree, because ...", 
9. Teachers provide evaluation and conclusions on the learning and material that has been discussed.

During the activity, students are very happy in searching for words in a predetermined way, although at first there were students who objected because they did not dare to ask the words to others and convey their opinions in front of his friends, but after being motivated then the students brave themselves and they feel happy and enthusiastic.

The follow up of this research is the need for final stage or confirmation phase. This stage aims to ensure that by applying the learning model find it students' literacy skills can be improved. This stage is carried out by giving questions about the material that has been discussed previously as 10 items and done by students for 10 minutes. The results of the research at the confirmation stage can be described as follows.

Table 2. Table of Action Results in the Final Stage for Literacy Ability and Mastery of Knowledge Vocabulary Competence of Fourth Grade Students of SDN Cibeber 1

\begin{tabular}{|c|c|c|}
\hline Category & Results & Information \\
\hline $\begin{array}{l}\text { Literacy skills } \\
\text { b. Write } \\
\text { c. Read } \\
\text { d. Asking } \\
\text { e. Answer } \\
\text { f. Bring ideas } \\
\text { b. g. Solve the problem }\end{array}$ & $\begin{array}{l}\text { The average percentage } \\
\text { of students' literacy } \\
\text { ability is about } 82.65 \%\end{array}$ & $\begin{array}{l}\text { In general, literacy } \\
\text { ability of fourth grade } \\
\text { students of SDN Cibeber } \\
1 \text { belong to category B }\end{array}$ \\
\hline $\begin{array}{l}\text { Mastery of vocabulary } \\
\text { knowledge } \\
\text { a. Average percentage } \\
\text { b. Percentage of classical } \\
\text { mastery }\end{array}$ & $\begin{array}{l}77,80 \% \\
76,55 \%\end{array}$ & $\begin{array}{l}\text { In general, the mastery of } \\
\text { students' vocabulary } \\
\text { knowledge is still } \\
\text { classified in category B } \\
\text { with classical } \\
\text { completeness belonging } \\
\text { to category B }\end{array}$ \\
\hline
\end{tabular}

Based on the exposure of early stage data analysis and confirmation phase, students' literacy ability at the confirmation stage showed that the percentage of the average percentage of students' literacy ability of $82.65 \%$ was in category B. Average value of students' vocabulary knowledge knowledge of $77.80 \%$ or in category B with a percentage of classical completeness of $76.55 \%$ or is in category B. This means that there is a percentage increase from the previous stage implementation which the average percentage of students' literacy ability is only $68.75 \%$ category $\mathrm{C}$, and the percentage of average the knowledge of vocabulary knowledge is only $65.48 \%$ or is in category $\mathrm{C}$ with the percentage of classical completeness is only $40.76 \%$ or is in category $\mathrm{C}$. 
Based on the above description of the increase in the results obtained literacy skills and the mastery of the students' vocabulary knowledge at the confirmation stage has reached the indicator of success. The recapitulation of literacy capability data and mastering the knowledge of grade IV vocabulary SDN Cibeber 1 in the early stages, and the final stage can be seen in the following table.

Table 3. Recapitulation Table Literacy Ability and Knowledge Mastery of Early and Final Words of Treasury

\begin{tabular}{l|l|l|l} 
Variables & $\begin{array}{l}\text { Percentage } \\
\text { average literacy } \\
\text { ability }\end{array}$ & $\begin{array}{l}\text { The average } \\
\text { percentage of } \\
\text { vocabulary } \\
\text { knowledge } \\
\text { acquisition }\end{array}$ & $\begin{array}{l}\text { Percentage mastery } \\
\text { of classical mastery } \\
\text { of vocabulary } \\
\text { knowledge }\end{array}$ \\
\hline Early stage & $68,75 \%$ & $65,48 \%$ & $40,76 \%$ \\
\hline The final stage & $82,65 \%$ & $77,80 \%$ & $76,55 \%$
\end{tabular}

Based on the recapitulation of the data, it can be presented on the histogram picture of the percentage increase of average literacy ability of the students and the average percentage of mastery of the vocabulary knowledge before the research and after the research as follows.

Figure 1. Graph of Improved Literacy Capability and Mastery of Knowledge of Vocabulary of Fourth Grade Students of SDN Cibeber 1

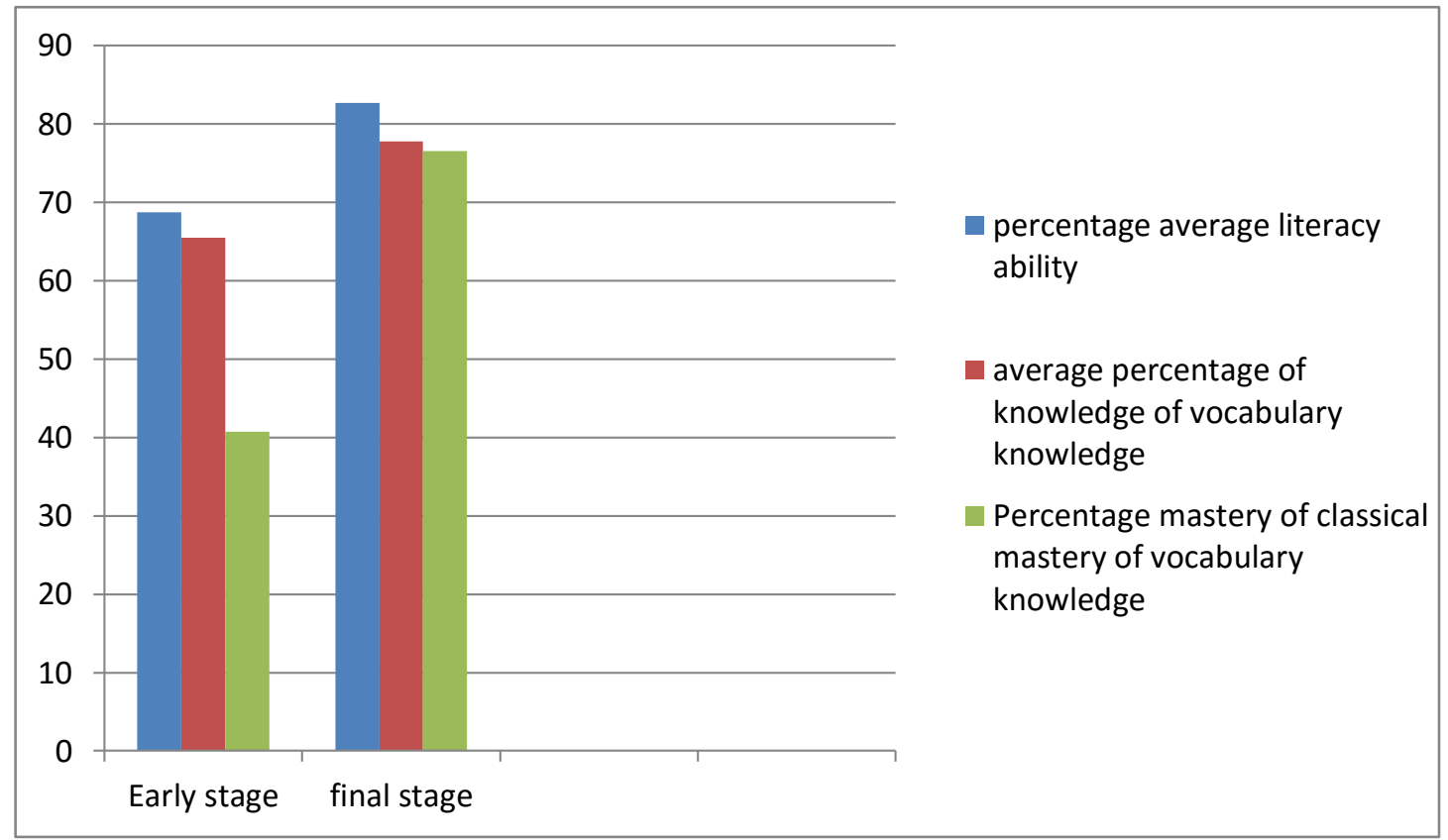

Based on the tables and graphs, it can be seen that there has been an increase in the literacy ability and the mastery of the students' vocabulary knowledge, that is, the average percentage by giving the action through the implementation of finding it model in fourth 
grade students SDN Cibeber 1. Achievement and improvement of literacy and mastery of vocabulary knowledge of students at the stage of giving a special way has reached the indicator of success in research. Student literacy skills are in the category of success, the mastery of students' vocabulary knowledge is in the high category in the final stage. Thus, this research succeeded in increasing the activeness and mastery of literacy ability and mastery knowledge of the vocabulary of fourth grade students SDN Cibeber 1 year lesson $2017 / 2018$.

\section{CONCLUSIONS}

Judging from the results of research in the fourth grade at SDN Cibeber 1 can be concluded that learners will be better able to develop their abilities by learning using learning model find it. In contrast to learning that does not use the learning model, during student learning looks passive. Learning is still centered on teachers who give more lectures than activities that involve students actively in learning. Learning by not using the learning model resulted in students very dependent on the teacher, this resulted in less than optimal student learning outcomes. So that students only accept what the teacher submits and the learning process tends to be boring as well as the literacy that students have can not develop properly.

Based on the conclusion, it can be proposed some suggestions that is for students, by applying the learning model find it is expected that students become active in following the learning process and get a more enjoyable learning experience and meaningful so that students are able to achieve optimal learning outcomes. This research is far from perfect, so researchers invite other researchers to continue this research.

\section{ACKNOWLEDGMENTS}

Researchers would like to thank all those who have supported this research both in terms of morale and material, especially at the IKIP Siliwangi and SDN I Sukaraja Sukabumi.

\section{REFERENCES}

Amirin. (2011). UNESCO (United Nations Educational, Scientific and Cultural Organization).

Cromley, J. (2000). Learning to think, learning to learn: what the science of thinking and learning has to offer adult education. Washington, DC: National Institute for Literacy

DePorter, Bobbi \& Hernacki, Mike. (2006). Quantum learning: membiasakan belajar nyaman \& menyenangkan. Bandung: PT.Mizah Pustaka

Kdk Ratih Pramita Dewi, Wyn Sujana2, M.G Rini Kristiantari3. (2016). e-Journal PGSD Universitas Pendidikan Ganesha Jurusan PGSD Vol: 4 
Kern, Richard. (2000). Literacy and language teaching. Oxpord Newyork: Oxpord University Press.

Sugiyono. 2004. Metode Penelitian Bisnis. Bandung: Alfabeta

Sukmadinata, Nana Syaodih. (2005). Landasan psikologi proses pendidikan. Bandung: PT Rosda Karya. 